\title{
Exploring the Subject of Simulated Practical Teaching Method in Insurance Bilingual Courses
}

\author{
Xue Dang \\ Dept. of economics \\ Guangdong University of Foreign Studies South China Business College \\ Guangzhou, China \\ 214003@gwng.edu.cn
}

\begin{abstract}
China was the biggest contributor to global life premium growth nowadays, a large number of insurance professionals are needed, and business must operate in an increasingly complex, global environment that generates many risks, etc. Talent cultivation in universities should keep steps to the economic and social demands in China. This paper analyzes the current conditions of insurance specialty, and examines a system of simulated practice teaching methods in the bilingual courses. College students are supposed to analyze the international and domestic insurance market and apply these knowledge based on what they have learned under this method. This paper also points out the key problems that should be paid attention to in the method's implementation.
\end{abstract}

Keywords-Insurance growth; Simulated practice teaching method; Bilingual course

\section{INTRODUCTION}

Experience has shown that Chinese people have a increasing demand for insurance provision, e.g. for property covers or health costs.( Table I)

In global terms, growth in China's GDP was considerable in 2017 at $6.7 \%$ when adjusted for inflation. Experts expect a significant increase in insurance sector. Until 2020 experts predict average growth of almost $12 \%$ for the insurance sector (Table II).

TABLE I. INSURANCE PENETRATION 2017 AND FORECAST FOR 2020 IN CHINA

\begin{tabular}{|l|l|l|}
\hline & $\begin{array}{c}\text { Penetration 2017 } \\
\text { as \% of GDP }\end{array}$ & $\begin{array}{c}\text { Penetration 2020e as \% } \\
\text { of GDP }\end{array}$ \\
\hline Insurance overall & 4.2 & 5.2 \\
\hline Life & 2.4 & 3.1 \\
\hline Non-life & 1.8 & 2.1 \\
\hline \multicolumn{2}{|c|}{${ }^{\text {a. }}$ Source: Munich Re Economic Research }
\end{tabular}

TABLE II. GDP AND INSURANCE SECTOR GROWTH IN CHINA

\begin{tabular}{|l|l|l|}
\hline & $\begin{array}{c}\text { Average } \\
\text { inflation-adjusted } \\
\text { annual growth } \\
\text { rate 2013-2017 }\end{array}$ & $\begin{array}{c}\text { Average inflation-adjusted } \\
\text { annual growth rate 2018- } \\
\text { 2020e }\end{array}$ \\
\hline GDP & $7.3 \%$ & $5.9 \%$ \\
\hline Insurance overall & $14.3 \%$ & $11.8 \%$ \\
\hline Life & $12.7 \%$ & $13.2 \%$ \\
\hline Non-life & $16.5 \%$ & $9.7 \%$ \\
\hline
\end{tabular}

Global life premiums increased only marginally by $0.5 \%$ in 2017, but in emerging markets, life premium growth remained strong at $14 \%$, mainly driven by China. Global nonlife insurance premiums increased $2.8 \%$ in 2017, whereas China had the speed of expansion $10 \%$.

As China was the biggest contributor to global life premium growth in 2017,a large number of insurance professionals are needed, especially undergraduate talents. It is expected that only an over 9\% annual increase of expert professionals can satisfy the rapid development of insurance industry in 50 years. Till 2050 the total demand of expert professionals would reach 10 million.

Unfortunately, only a several universities have set up insurance specialties or deliver the insurance academic courses, which could not keep up with the rapid booming speed of Chinese insurance market .The supply and demand ratio which is approximately 1 to 4 badly mismatches the market's huge potentials. The contradiction between supply and demand of insurance talents is especially prominent.

On the one hand, professional skills of students in colleges and universities are not strong, always lack of applied compound talents. University teachers generally have admitted a lack of practical experience about their subjects, teaching content and form lags behind industry's real economy. Insurance companies have rich education resources with low training costs and well-targeted incentives. Insurance companies have systems of their own with strong abilities of practical trainings.[1]

On the other hand, trainings held by insurance companies usually have the characters of short-term and emergency but no systematicness. They put emphasis on skills and technique, ignoring the theory. Whereas these kinds of trainings have little help to upgrade employees' and agents' overall standards.

Insurance Industry Association announced to kick off "the thousand talents plan" in may $28^{\text {th, }}$ 2014. This plan meaned to develop a group of creatively applied talents to establish and improve the human resource reserve in insurance industry.

In August 31"th, 2016, the CIRC delivered the "The 13th Five-year Plan of insurance industry" which explicitly raised the full implementation of the talents strategy adapt to the requirement of industry.

Supported by the key quality project of SCBC's educational administration office (2015JG08) 
Therefor talent cultivation in universities should keep steps to the economic and social demands in China. The author analyzes and constructs a system of simulated practice teaching methods in the bilingual courses in this article.

\section{REORGANIZAION OF RESEARCH LITERATURE}

The research literature of simulated practical teaching method include the following parts: importance, the orientation, educational objectives, discipline construction and talents cultivation.

Half of the researchers emphasize the importance of higher education for insurance industry, Deng yong(2012) and Ye an(2010) regarded that we need more talents to fill the gap left by the increasing demand. Some researchers stand in the position of the nature in insurance discipline, which they put forward the opinion that insurance should be regarded as applied economics. Professor Zhao guoji(2013) and Dong zhengchun(2011) pointed out that universities should cultivate the innovatively practical talents.

Scholars carry out some strategies for the talent cultivation. Wang jun(2012) thought the settlement of the courses curriculum should combine the industry practice. Zhou yi (2013) put importance on the construction of practice base and shool-enterprise cooperation. Liu yingyuan(2014) suggested that teachers in professional colleges must specialize in both theory and practice.

Some scholars analyzed innovation of the teaching methods and effect. Brown, Collins and Duguid(1989) put forward the theory of situated cognition and learning in their book "situated cognition and learning culture". They wrote that "knowledge is situated in a scene and is progressed and develops in behavior, whereas situation is the basis of all cognitive activities."

Professor Yu yang(2010) advocated the simulated practical teaching method, under which refer to the teaching content teachers use various media to create scenes similar to the real environment so that the students could play roles to carry out simulation of practice activities.

Roth(1997) and Wenger(2006) concluded that practical entity usually had three characteristics: common task, mutual intervention, shared resource.

Chang wei(2014) regarded that more scenes and cases should combined in the insurance simulated practical teaching method.

\section{BAsic ObJectives Of The Bilingual Course ON INSURANCE IN CHINA}

These kind of courses explores the areas of general risk management process, property and liability insurance, life and health insurance, annuities and employee benefits. The students will learn to identify and measure risks, and select appropriate risk management tools to reduce and finance risks. [1]

The purpose of the course is to equip students to develop a conceptual framework for making risk management decisions that increase business value and individual welfare, to get familiar with the insurance industry, Furthermore, to discuss the topics related to the Chinese insurance industry.

The courses would analyzes the basic contractual provisions that appear in life and health insurance or property and liability insurance contracts, many of which are required by state law. Students should be able to understand most provisions without extensive discussion. It is worthwhile to discuss briefly the additional life insurance benefits that can be added to a policy.

The students should be made clear that business must operate in an increasingly complex, global environment that generates many risks which are often associated with property losses, legal liability, workplace injury and employee benefits, currency exchange, interest rate fluctuations and political risks.

They should realize what had happened in China's insurance market, the hot topics related to the Chinese insurance industry will be discussed and analyzed based on the textbook's foundations. The course addresses the unprecedented events that have occurred in today's economy, highlighting the destructive presence of risk to students.

So in these courses teachers should not only use one single teaching method, should not only focus on the theory, should not make narrow nor obsolete curriculum, and must specialize in theory or practice. The author suggests a system of simulated practice teaching methods in the bilingual courses be constructed and applied.

\section{THE SIMULATED PRACTICAL TEACHING METHODS SHOULD BE DELIVERED IN INSURANCE BILINGUAL COURSES}

The traditional teaching methods in Chinese college include multimedia, Powerpoint, board writing and lectures ect. Using the simulated practical teaching methods, we can start from the following points.

\section{A. Design of Teaching Objectives}

Using the simulated practical teaching methods in insurance bilingual courses, the first step is to make sure what kind of talents should the college cultivate and what kind of teaching objectives should be achieved?[2]

Except for the basic knowledge, theories and principles, students should make a better understanding of the whole insurance workflow, like the marketing process, the purchasing process, underwriting and policy issue process, the claim process ect. Let the students act as different roles to make a better understanding of the whole operation process in insurance industry, and preliminarily apply those knowledge in practice.[3]

\section{B. Selection of Teaching Content}

Teaching content should be suitable for the situation. Although insurance is a highly applied discipline, not all teaching contents are suitable. Some practice such as insurance business operation are highly situational. For example, teachers can carry out the auto insurance underwriting practical simulation.[4]

And what's more, the teaching content should not be restricted to one leaning point. The simulation of real 
conditions can be diversified and multi-level, considering the correlation of knowledge. As for the auto insurance underwriting practical simulation, its leaning points can include auto insurance's lines, insured subject, insurable interest, assurance confirmation, insured liability, exclusions, premiums calculation, risk recognition, application management ect.

\section{Simulated Practice Time Arrangement}

Let' s take the textbook of George Rejda's "Principles of Risk Management and Insurance" as an example , part 1 discuss theory of foundations, Part 2 examine operation rules of the private insurance, Part 3 deliver the law rule and principles. The practical part like operation rules which include underwriting, claim, actuary could apply the simulated teaching method. The further understanding of insurance lines such as life \&health insurance or property \& liability insurance, students may be assumed to be the policyholder or the agent to simulate the insurance purchase process. It is not recommended that all practices in these parts be carried out during the course of teaching insurance, because there is one restriction of teaching time - the learning credit hours allocated to simulated practices are limited. And what' $\mathrm{s}$ more, some practices can be carried out in other courses.

\section{Software and Hardware Supporting}

Underwriter laboratories which should be equipped with enough computers, so that every student has the chance to operate in person. The teacher needs to demonstrate the software operation through the projector on the rostrum and tell the students what to do and explain the various options in the system represent the meaning. For example, click "save" can also modify the answer, click "submit" can no longer modify the answer.

Suppose that our school can use a personal insurance and property insurance software which is designed by an application software company. Teachers can use their accounts to assign the tasks. Students then enter their own interface to find the assigned tasks. Play different roles to complete the task of each page. Finally, the details of students' operation are reflected in the form of experimental reports.[5]

In addition to select existing business in the system, teachers can also design some particular tasks by themselves in the system and let the students excecute the assignments to achieve their target.

\section{E. Role Simulation Participation}

Take property insurance as an example, teachers login system ready for the class, choosing family property insurance, choosing class. Students can see the assigned tasks when they login in class and what is needed such as relevant information of customers, banks, insurance companies, etc. to complete the tasks.[5]According to these data, students can simulate customers, insurance companies, underwriting process, and make relevant documents. For example, students should first act as customers to fill out the application form, then a business person to accept the insurance policy and fill in the relevant information, finally a financial officer with printing a transfer receipt etc. After these steps, students should submit to see the correct answer and examine in which step they have done wrong, and finally carry out an experimental report.

During simulated practical process mentioned above, note that as for the insurance market, three areas should be emphasized to make the students have good participation in the roles. First, because of the Financial Modernization Act of 1999, insurers also market a wide variety of investment products. Second, emphasize that the corporate structure is changing because of mergers, demutualization, and the formation of holding companies. Finally, emphasize that insurers often use multiple-marketing system to sell their products.

\section{PROBlems that MUST BE PAID ATtENTION TO}

\section{A. Attaching Importance to the Construction of Case Base}

Success of case base construction is one of the key steps to the simulated practical teaching method. The insurance case is an objective description based on facts. Case teaching focuses on discussion. Using the simulated practical teaching methods in insurance bilingual course, guide the students into character, experience on the scene. The collection of cases must be close to insurance practice. Teachers should pay attention to timeliness, we must keep pace with the real world to select the latest cases as far as possible. It contains both insurance principles and insurance practices. We still take the textbook of George Rejda's “Principles of Risk Management and Insurance" as an example, some abstract theoretical part especially need the case base supporting, like the principle of insurance law, the insurance contract. Case base help students analyzes the basic contractual provisions that appear in life and health insurance or property and liability insurance contracts using simulated practical teaching methods. Only the rich base could satisfy the needs of simulated practical teaching methods.[6]

\section{B. Practical and Theoretical Courses are Equally Important}

Practical course should not be considered an accessory of theoretical courses. The curriculum of practice should be reasonable. Term should be well-distributed. Practical course involves experiment, practice and graduation design. Students take an active part in it. They attach great importance to students' thinking ability to solve practical problems and teamwork.

Insurance need strong professional background, such as engineering insurance and claims. Engineering insurance will involve engineering mechanics and other disciplines knowledge, while claims will involve knowledge of law ect.

Students can choose Interdisciplinary elective courses like these kinds. Choosing these courses have great freedom, and they can give full play to one's interests and advantages. As for the specific circumstances of each school, it depends on the idea depth or breadth? Training objectives should be very clear.

\section{Supporting Reform of Student Evaluation System}

Teaching reform is a systematic project. The change of teaching methods needs to be matched with its teaching management and assessment system. If we can adjust the 
assessment methods and criteria in the curriculum, It will be helpful to improve simulated practical teaching effect. It refers to the assessment of a student's mastery of knowledge not just by the scores on a one-time examination at the end of the course. It is to observe students' performance combined with usual discussions, exercises and safety reports, and to add more topics of subjective discussion, pay attention to the assessment of students' learning process and ability to analyze problems. This supporting system are so valuable for teachers to deliver the simulated practical teaching methods. Note that teachers should pay attention to the assessment of students' learning process and ability to analyze problems. And what' $s$ more, keep in mind that students must master a certain amount of new insurance terminology. Studying insurance is the equally important with becoming fluent in a foreign language. The student starts by building upon a basic vocabulary. The same is true for insurance. Insurance is a technical subject that requires a basic foreign vocabulary of specialties. We should follow the path of open education by delivering the simulated practical teaching methods and adhere to the internationalization and marketization of insurance higher education.[7]

\section{CONCLUSION}

The simulated practical teaching methods have the characters of practicalness, interactivity, collaboration, creativity and fun. Teachers use various media to create scenes similar to the real environment so that the students could play roles to carry out simulation of practice activities. It can satisfy the target for innovative insurance talents cultivations and be widely used in insurance bilingual courses. But note that the supporting system should catch up like the cases base construction, the students evaluation reform and the practical curriculum settlement ect. The simulated practical method is a new teaching method in China, only through the reform and exploration can we make the insurance specialty service the society and cultivate the application-oriented talents.

\section{REFERENCES}

[1] Y.L. Zhou, "Push the development of higher education in insurance disciplines," insurance research, vol. 2007(11), pp. 3-6, 2007.

[2] Y.Y. Liu, "Analyze the problem and effect of the talent cultivation in higher education of insurance disciplines," new course research, 2014 (1).

[3] E. Wenger, Communities of practice:A brief introduction[EB/OL][201205-16], 2006, http://www. ewenger.corn/theory/.

[4] Y. Yu, "Discussion on simulation experiment teaching of insurance specialty," the guide of science \& education, vol. 2010(2), pp. 2930,2010 .

[5] B.L. Zhang, "Design and application of insurance simulation teaching," economic research guide, vol. 2014(31), pp. 185-186, 2014.

[6] L.L. Qin, "Application of PBL teaching method in Insurance disciplines," financial theory and teaching, 2012 (1), pp. 100-101.

[7] W.M. Roth, Designing communities, Dordrecht: Kluwer Academic Publisher, 1997. 